\title{
Long-term protection against SHIV89.6P replication in HIV-1 Tat vaccinated cynomolgus monkeys
}

\author{
Maria Teresa Maggiorella ${ }^{\mathrm{a}}$, Silvia Baroncelli ${ }^{\mathrm{a}}$, Zuleika Michelini ${ }^{\mathrm{a}}$, Emanuele Fanales-Belasio ${ }^{\mathrm{a}}$, \\ Sonia Moretti ${ }^{\mathrm{a}}$, Leonardo Sernicola ${ }^{\mathrm{a}}$, Andrea Cara ${ }^{\mathrm{a}}$, Donatella R.M. Negri ${ }^{\mathrm{a}}$, Stefano Buttò ${ }^{\mathrm{a}}$, \\ Valeria Fiorelli ${ }^{\mathrm{a}}$, Antonella Tripiciano ${ }^{\mathrm{a}}$, Arianna Scoglio ${ }^{\mathrm{a}}$, Antonella Caputo ${ }^{\mathrm{b}}$, \\ Alessandra Borsetti ${ }^{a}$, Barbara Ridolfi ${ }^{a}$, Roberta Bona ${ }^{a}$, Peter ten Haaft ${ }^{c}$, Iole Macchia ${ }^{a}$, \\ Pasqualina Leone $^{\mathrm{a}}$, Maria Rosaria Pavone-Cossut ${ }^{\mathrm{a}}$, Filomena Nappi ${ }^{\mathrm{a}}$, Massimo Ciccozzi ${ }^{\mathrm{d}}$, \\ Jonathan Heeney ${ }^{\mathrm{c}}$, Fausto Titti ${ }^{\text {a }}$, Aurelio Cafaro ${ }^{\mathrm{a}}$, Barbara Ensoli ${ }^{\mathrm{a}, *}$ \\ a Laboratory of Virology, Istituto Superiore di Sanità, Viale Regina Elena, 299, 00161 Rome, Italy \\ ${ }^{\mathrm{b}}$ Department of Experimental and Diagnostic Medicine, University of Ferrara, 44100 Ferrara, Italy \\ c Department of Virology, Biomedical Primate Research Centre, ZH 2288 GJ Rijswijk, The Netherlands \\ ${ }^{\mathrm{d}}$ Laboratory of Epidemiology and Biostatistics, Istituto Superiore di Sanità, 00161 Rome, Italy \\ Received 15 July 2003; received in revised form 19 February 2004; accepted 10 March 2004
}

Available online 8 April 2004

\begin{abstract}
Vaccination with a biologically active Tat protein or tat DNA contained infection with the highly pathogenic SHIV89.6P virus, preventing CD4 T-cell decline and disease onset. Here we show that protection was prolonged, since neither CD4 T-cell decline nor active virus replication was observed in all vaccinated animals that controlled virus replication up to week 104 after the challenge. In contrast, virus persisted and replicated in peripheral blood mononuclear cells and lymph nodes of infected animals, two of which died. Tat-specific antibody, CD4 and CD8 T-cell responses were high and stable only in the animals controlling the infection. In contrast, Gag-specific antibody production and CD4 and CD8 T-cell responses were consistently and persistently positive only in the monkeys that did not control primary virus replication. These results indicate that vaccination with Tat protein or DNA induced long-term memory Tat-specific immune responses and controlled primary infection at its early stages allowing a long-term containment of virus replication and spread in blood and tissues.
\end{abstract}

(C) 2004 Elsevier Ltd. All rights reserved.

Keywords: HIV vaccine; Tat; Macaca fascicularis

\section{Introduction}

Tat is a key viral regulatory protein of human immunodeficiency virus (HIV) produced very early after infection even prior to provirus integration [1-3]. Tat is essential for viral replication, transmission and disease progression [1,4-7]. In addition, Tat can modulate the expression of cytokines and cellular genes [6-11], and chemokine receptors [12-15], which are responsible for the transmission of macrophageand T-cell-tropic HIV-1 strains, respectively. In addition, the Tat protein also plays key roles in viral pathogenesis and in

\footnotetext{
* Corresponding author. Tel.: +39-06-4990-3209; fax: +39-06-4990-3002.

E-mail address: ensoli@iss.it (B. Ensoli).
}

the pathogenesis of acquired immune deficiency syndrome (AIDS)-associated Kaposi's sarcoma [8,16-22].

Several studies suggest that an immune response to Tat has a protective role and may control the progression of the disease in vivo. Specifically, antibody $(\mathrm{Ab})$ responses to Tat have been associated with non-progression to AIDS [23-28]. Similarly, anti-Tat CTLs have been shown to inversely correlate with progression to AIDS [29,30]. Of importance, Tat is conserved in its immunogenic regions among all $\mathrm{M}$ subtypes, and Tat B clade is recognized to the same extent by sera from South African, Ugandan and Italian individuals infected with A, B, C and D virus clades [28]. Further, studies in humans $[29,30]$ and in monkeys indicate that anti-Tat CTLs are key to control virus replication early after primary infection, and that they exert a selective immune pressure on the virus leading to the appearance of slowly 
replicating and apparently less pathogenic escape mutants [31].

Taken together, this body of evidence suggests that immunization with Tat may block HIV replication both in individuals exposed to the virus after vaccination and in seropositive patients, reducing HIV infection and favouring its control by the mounting immune response. In this regard, some features of the Tat protein are relevant to Tat-based vaccine development. First, we have recently shown that biologically active native HIV-1 Tat protein, but not its oxidized counterpart, is taken up very efficiently and selectively by monocyte-derived dendritic cells and induces their maturation and antigen presenting function, driving Th-1 type immune responses [32]. Secondly, soluble Tat protein has been shown to enter the major histocompatibility complex (MHC) class I pathway of antigen presentation, leading to elicitation of cytotoxic T lymphocytes (CTLs) [33].

Pre-clinical studies in mice and monkeys have shown that vaccination with a biologically active native HIV-1 Tat protein or with tat DNA is safe [34-38], elicits both humoral and cell-mediated Tat-specific immune responses [34-38], and, in cynomolgus monkeys, controls infection with the highly pathogenic SHIV89.6P virus, preventing CD4 T-cell decline and disease onset in the protected animals [34-36]. Similar results of protection were reported in the SIV model with viral vectors (Semliki Forest Virus and Modified Vaccinia Ankara Virus) expressing the SIV-Tat and -Rev genes [39]. Of importance, injection of plasmid DNA coding for the HIV-1 regulatory genes Nef, Rev and Tat was reported to be safe and immunogenic in HIV-1 infected individuals [40,41].

Since Tat vaccination does not prevent infection but controls virus replication and disease onset, it is key to investigate whether protection is long-lasting, and to determine the level of virus infection, reservoir, and replication over time in the protected animals. Therefore, we extended the analysis of the vaccinated and control macaques up to 2 years after the challenge, looking for signs of virus persistence and replication in blood and lymph nodes and for persistence and development of CD4 and CD8-mediated immune responses to HIV-1 Tat and SIV Gag, respectively.

The results indicate that vaccination with either a biologically active Tat protein or tat DNA induces a long-term protection (i.e. containment of infection) against challenge with the highly pathogenic SHIV89.6P virus, which is associated with the absence of detectable virus replication both in blood and tissues and with the persistence of Tat-specific T- (both CD4 and CD8) and B-cell memory responses.

\section{Materials and methods}

\subsection{Vaccination protocol and virus challenge}

Adult male cynomolgus monkeys (Macaca fascicularis) were housed in single cages within level three biosafety fa- cilities according to the European guidelines for non-human primate care (EEC, Directive No. 86-609, 24 November 1986). Blood samples were obtained from the inguinal vein while the animals were under ketamine hydrochloride anesthesia $(10 \mathrm{mg} / \mathrm{kg})$. Clinical examination and weight measurement were performed at the time of blood collection. At each time-point bleedings were performed for routine blood chemistry tests and immunological determinations. The vaccination protocols and schedules have been reported elsewhere [34-36]. After 14-18 weeks from the last boost, all animals were challenged intravenously (i.v.) with $10 \mathrm{MID}_{50}$ of the SHIV89.6P virus, a highly pathogenic SHIV containing the tat gene of HIV-1. The virus stock used was derived from a cynomolgus macaque inoculated with the original SHIV89.6P from rhesus monkeys [42]. Both the original viral stock grown in a rhesus macaque and the one grown in a cynomolgus monkey were highly pathogenic in $\mathrm{M}$. fascicularis $[34,35]$. The pathogenicity in cynomolgus monkeys of both virus stocks was confirmed by the progression to AIDS and death (within 46 weeks from the inoculum) of four out of six and four out of seven cynomolgus monkeys infected, respectively, with the rhesus- or cynos-derived viral stock [35]. The two naive control animals, monkeys 2 and 12 , included as additional control at the time of the challenge, were inoculated with a three-fold higher $\left(28 \mathrm{MID}_{50}\right)$ or three-fold lower (2.8 $\left.\mathrm{MID}_{50}\right)$ viral inoculum, respectively [34-36].

\subsection{Detection of anti-SIV and anti-HIV Env and p27 Gag antigen in plasma}

Ab titers to the whole SIV were determined by endpoint dilution of plasma samples using a HIV-2 enzyme-linked immunosorbent assay (ELISA) (Elavia AC-Ab-Ak II Kit, Diagnostic, Pasteur) according to the manufacturer's instructions. Ab titers against the HIV-1 Env were detected by an HIV-1 ELISA assay (HIV-1/HIV-2 Third Generation Plus, Abbott, Chicago, IL). The mean of the negative control plus 3 S.D. represented the cut-off value.

Levels of p27 Gag protein were measured in plasma by using a capture ELISA assay (Innotest, Innogenetics, Zwijndrecht, Belgium) with a detection limit of $20 \mathrm{pg} / \mathrm{ml}$.

\subsection{Quantitation of the SHIV RNA copies in plasma}

Until week 14 post-challenge quantitation of SHIV89.6P RNA copies was performed only in the Bayer-Chiron Diagnostics reference Testing Laboratory (Amsterdam, The Netherlands) by a branched DNA (bDNA) signal amplification assay recognizing the pol region of the SIVmac251 strain, as described [34], with a cut-off of 1,500 RNA copies/ml. Between week 14 and 28 post-challenge quantitation of SHIV89.6P RNA copies was performed by both the bDNA method and by a more sensitive quantitative competitive RNA-polymerase chain reaction (QC-RNA-PCR, cut-off: 50 RNA copies/ml) as already described [43]. Since 
week 35 post-challenge, quantitation of SHIV89.6P RNA copies was performed only by QC-RNA-PCR.

\subsection{Proviral DNA detection}

DNA was extracted from whole blood using the QIAamp Blood Kit (QIAGEN, GmbH, Hilden, Germany) or from lymph node cells using the phenol-chloroform method, followed by precipitation with $3 \mathrm{M}$ sodium acetate and cold ethanol. SHIV proviral copy number was determined by a semi-quantitative DNA PCR utilizing $1 \mu \mathrm{g}$ of DNA and amplifying a $496 \mathrm{bp}$ region of the gag gene of SIVmac239, as already described $[34,36]$. The lower limit of detection was

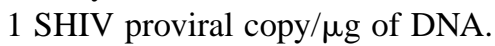

\subsection{Unintegrated virus DNA detection}

For analysis of viral extrachromosomal circular DNA (E-DNA), DNA was extracted from lymphocytes $((2-5) \times$ $10^{6}$ ) using the QIAprep Spin Miniprep Kit in order to enrich for the low molecular weight DNA fraction, and analyzed by PCR for the presence of circular forms of viral DNA as described $[44,45]$. Twenty microliters of the total volume $(50 \mu \mathrm{l})$ were denaturated at $95^{\circ} \mathrm{C}$ for $5 \mathrm{~min}$, and subjected to 40 cycles of PCR with an annealing temperature of $60^{\circ} \mathrm{C}$ for $30 \mathrm{~s}$, an extension temperature of $72^{\circ} \mathrm{C}$ for $30 \mathrm{~s}$ and a denaturation temperature of $95^{\circ} \mathrm{C}$ for $30 \mathrm{~s}$, using primers FORN15'-GTGACTCCACGCTTGTTTGC- $3^{\prime}$ (forward), located in the R LTR region, and REVN15'-CTCCTGTGCCTCATCTGATACA-3' (reverse), mapping in the U3 LTR region of the SIVmac239. The amplified fragment was $361 \mathrm{bp}$ in length. As positive control, a reference standard was prepared by cloning the PCR product, amplified from DNA of CEMx174 chronically infected with SHIV89.6P, into the pCR 2.1 vector (Invitrogen, Carlsbad, CA).

Hybridization was performed according to established procedures [46] utilizing the FORN1/REVN1 PCR product as probe.

\subsection{Virus isolation and cell associated viral load (cytoviremia)}

Virus isolation and cytoviremia were performed by co-culturing CD8-depleted PBMCs with CEMx174 cells in the presence of phytohemoagglutinin (PHA, $2 \mu \mathrm{g} / \mathrm{ml}$ ) and recombinant human interleukin-2 (rhIL-2) $(50 \mathrm{IU} / \mathrm{ml})$, as already described [34-36].

\subsection{Lymphocyte subsets determination}

Citrated peripheral blood cells were stained with phicoerythrin PE-conjugated anti-CD4 (Biosource International, Camarillo, CA) and peridin chlorophyll protein (PerCP)-conjugated anti-CD8 mAb (Becton-Dickinson, Mountain View, CA), and analyzed with a FACScan cytometer and software (Becton-Dickinson) as described
[34,36]. Absolute cell numbers were calculated from blood cell counts.

\subsection{Recombinant proteins}

The Tat protein (1-86 aa) from the HTLV-IIIB isolate, BH-10 clone (clade B), was expressed in E. coli, purified and stored as described earlier [9,32,34]. The purified Tat protein was fully monomeric and had full biological activity as assessed by virus transactivation assays and by uptake studies in monocyte-derived dendritic cells $[6,9,32,34]$. Tat used for in vitro studies was resuspended in degassed buffer before use as described $[6,28,34]$. The SIVmac251 p55 Gag recombinant protein was derived from baculovirus was obtained through Quality Biological, Inc. and the Vaccine Research and Development Branch, Division of AIDS, NIAID, NIH (Bethesda, MD).

\subsection{T-cell proliferation assays}

To evaluate the proliferative response to Tat, Gag and the recall antigen tetanus toxoid (TT), Ficoll-purified PBMCs $\left(2 \times 10^{5}\right.$ per well $)$ were seeded in flat bottomed 96-well microtiter culture plates in triplicates in a final volume of $200 \mu$ l of RPMI containing 10\% FCS (medium) and cultured either alone or in the presence of PHA $(2 \mu \mathrm{g} / \mathrm{ml})$, TT $(5 \mu \mathrm{g} / \mathrm{ml}$, Connaught, Ontario, Canada), Tat protein $(5 \mathrm{mg} / \mathrm{ml})$, SIVmac251 p55 Gag protein $(5 \mathrm{mg} / \mathrm{ml})$ or SIVmac239 p27 Gag 15mers peptides (aminoacid 226-240, 231-245, 236-250, 283-297, 289-303, 295-309 at 5 mg/ml each) or buffer [phosphate buffered saline (PBS) containing $0.1 \%$ BSA]. After 5 days of incubation at $37^{\circ} \mathrm{C}$ in $5 \% \mathrm{CO}_{2}$, cell cultures were pulsed with $1 \mu \mathrm{Ci} /$ well of $\left[{ }^{3} \mathrm{H}\right]$ thymidine (Amersham Life Science, Buckingamshire, UK) and the incorporated radioactivity was measured $18 \mathrm{~h}$ later, as previously described $[34,36]$. A stimulation index (SI) $\geq 3$ was considered positive.

\subsection{Interferon (IFN)- $\gamma$ ELISpot assay}

The number of IFN- $\gamma$ producing cells (spot forming cells, sfc) was measured by a commercial kit (Human IFN- $\gamma$ ELISpot, Euroclone, Paignton, UK), following the manufacturer's instructions. Briefly, PBMCs $\left(2 \times 10^{5}\right.$ per well, in duplicate) were cultured with medium alone or in the presence of PHA $(2 \mu \mathrm{g} / \mathrm{ml})$, TT $(5 \mu \mathrm{g} / \mathrm{ml})$, Gag or Tat protein $(5 \mu \mathrm{g} / \mathrm{ml})$, or buffer in flat bottomed 96 -well plates previously coated with a mAb to IFN- $\gamma$. After $18 \mathrm{~h}$, cells were removed and locally produced IFN $-\gamma$ was revealed by an immunoenzymatic reaction into a gel matrix as coloured spots. The spots, a measure of IFN- $\gamma$ producing cells, were counted under a light microscope and expressed as number of sfc per $10^{6}$ PBMCs upon subtraction of background counts. Based on data obtained with PBMCs from 24 naive monkeys, a number of sfc greater than $20 / 10^{6}$ cells was considered as a positive response to the antigen. 


\subsection{Lymph node biopsies}

Inguinal lymph nodes were removed surgically under ketamine hydrochloride anesthesia at week 55 after challenge from monkeys vaccinated with the pCV-tat, and at week 71 after challenge from monkeys vaccinated with the Tat protein and from control monkeys. The tissue was minced to obtain single cell suspension for virus isolation, quantitative detection of proviral DNA, and analysis for the presence of E-DNA forms, which were performed as described above.

\subsection{Statistical analyses}

The statistical significance of the differences between vaccinated and control monkeys during the course of infection was determined by the Fisher's exact test for quantitation of SHIV RNA copies in plasma and for SHIV DNA PCR and E-DNA analyses in lymph node biopsies. The Student's $t$-test for independent samples was used to assess differences between groups concerning the proliferative response and the IFN- $\gamma$ ELISpot to Tat and Gag antigens.

\section{Results}

\subsection{Long-term containment of virus replication in vaccinated and protected animals}

A total of 12 macaques were vaccinated with the Tat protein or the pCV-tat plasmid as two arms of the same protocol and challenged i.v. with SHIV89.6P, as reported in Section 2. The results of the immune response to Tat before the challenge, challenge outcome and virological data up to 46 weeks after challenge have been published elsewhere [34-36]. These results indicated that, although vaccination with the biologically active Tat protein or pCV-tat did not prevent virus entry, it contained primary infection in 9 out of 12 vaccinated animals. Therefore, the term protection, as used in the present study, refers to protection from virus replication and disease onset, that is control of infection, and not to prevention of infection. Consequently, animals were defined as controllers or non-controllers according to their virological status early after challenge.

To investigate whether control of infection was durable, all macaques (both vaccinated and controls) were monitored up to 104 weeks after the challenge for plasma viremia, circular viral DNA, proviral DNA and virus isolation both in blood and lymph nodes.

As shown in Fig. 1, plasma viremia remained undetectable in all (9/12) animals, which controlled primary virus replication (vaccinated and protected animals), whereas in the three vaccinated animals unable to control virus replication (monkeys 54963, 55396, and 37) plasma viremia either became undetectable early in the follow-up (week 23 for monkey 54963), or remained detectable with a further increase late in the follow-up (monkeys 55396 and 37) (Fig. 1A and
B). Viral RNA was also detected over time in all adjuvant control and naive control macaques. In particular, monkey 2 had high levels of viral RNA up to week 35 when was euthanised due to AIDS (Fig. 1C). Similarly, monkey 37 died of AIDS at week 75 after challenge. The comparison of plasma viremia data between vaccinated and control animals at week 4 after challenge revealed a statistically significant difference, as determined by the Fisher exact test $(P$-value $=0.019)$.

To better evaluate virus replication, E-DNA, a parameter more sensitive than the evaluation of plasma viremia [44,45], was measured in PBMCs of all macaques (with the exception of monkey 2) and compared with plasma viremia at early and/or late time points post-challenge (Fig. 1). A good correlation was observed between the presence of E-DNA and plasma viremia. However, E-DNA was also found in animals with undetectable plasma viremia, indicating the presence of low levels of persistent viral replication. In particular, E-DNA was positive at multiple time points post-challenge in all the non-controllers, both viremic and aviremic, whereas it was detected only once in three out of the nine controllers (plasma viremia always below the detection threshold) (Fig. 1).

The frequency of viral isolation also correlated with the presence of viral RNA in plasma. In fact, the virus was not isolated from any of the macaques controlling infection, even after depletion of the CD8+ T-cells. Conversely, it was frequently isolated from all the non-controllers ([34-36], and data not shown).

Similarly, after the challenge the provirus was either undetectable or sporadically present at a very low level $(<10$ copies/ $\mu \mathrm{g}$ of DNA) in the controllers, and always detected in all the non-controllers (Fig. 2A-C).

Consistent with the virological data, in all the controllers the number of CD4+ T-cells was in the normal range during the entire follow-up (104 weeks). In contrast, it decreased considerably in all the non-controllers (3/12 vaccinated and $4 / 4$ control macaques) (Fig. 3A-C). In particular, monkeys 2 and 37 had a sharp and profound CD4+ T-cell decline, developed AIDS and died.

Taken together, these results indicated that vaccinated and protected monkeys contained virus infection and replication during the all post-challenge follow-up (104 weeks). In contrast, all infected animals had higher levels of latent infection and showed a persistent virus replication in blood.

\subsection{Absence of a virus reservoir and virus replication in lymph nodes of vaccinated and protected macaques}

Since lymph nodes are a major virus reservoir, virus isolation and determination of integrated or unintegrated viral DNA were performed late after the challenge on lymph node biopsies (week 55 for the monkeys vaccinated with the pCV-tat and week 71 for monkey vaccinated with the Tat protein, the control monkeys and the naive monkey 12) and compared with the results obtained with PBMCs 

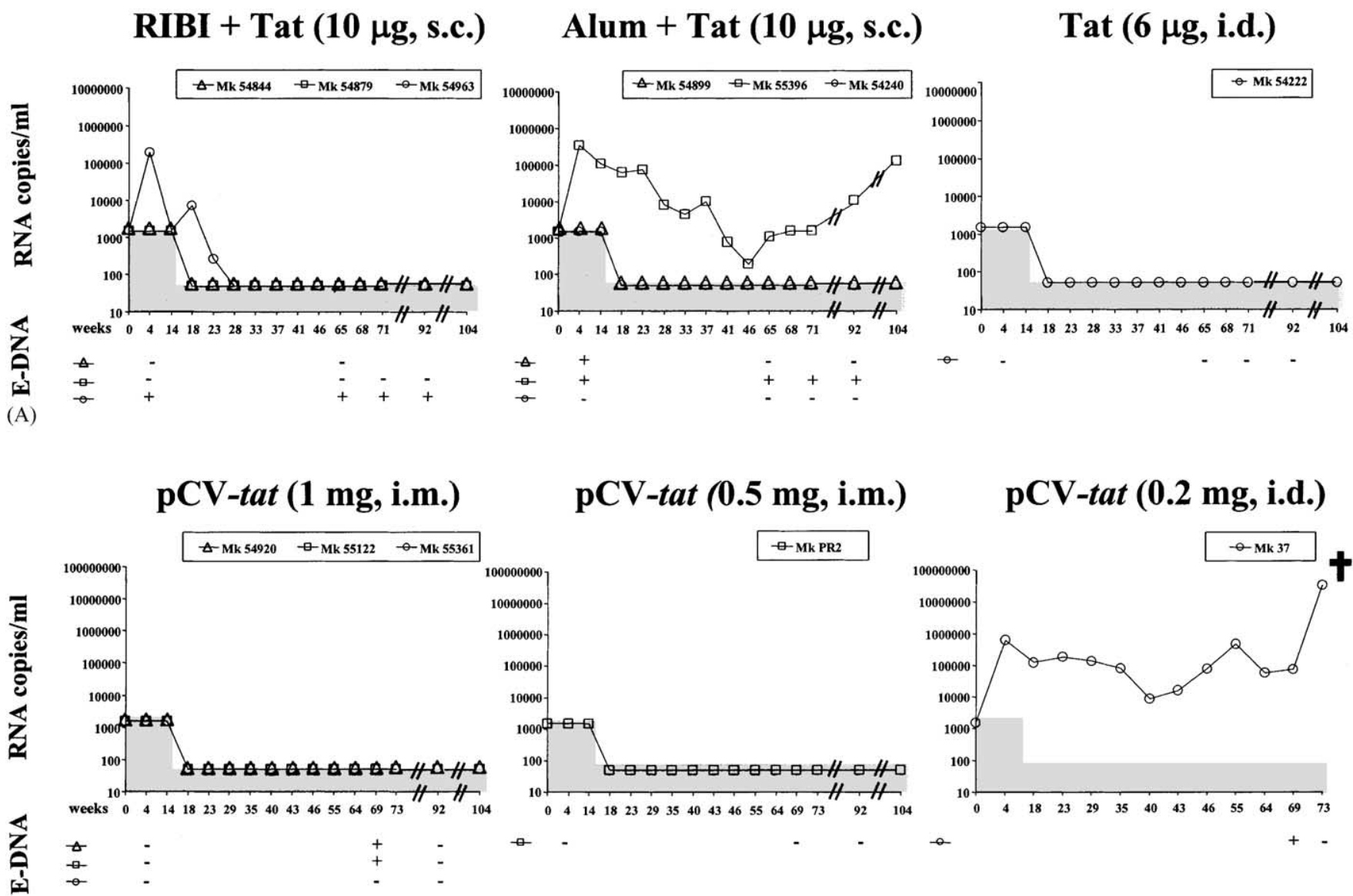

pCV-tat (0.2 mg, i.d.)

(B)

\section{Adjuvant Controls}

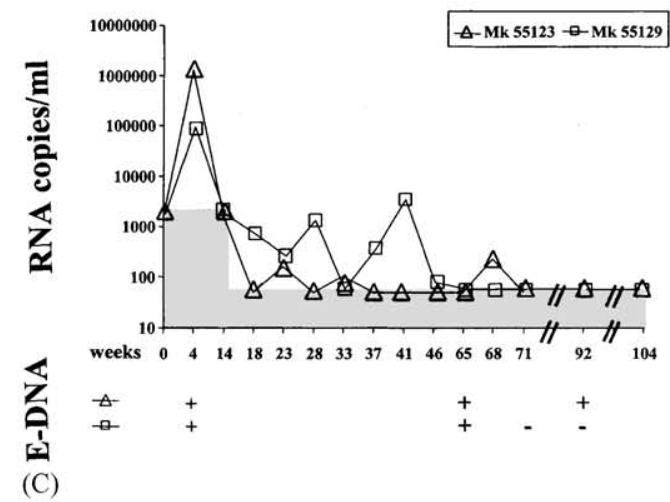

Naive Controls

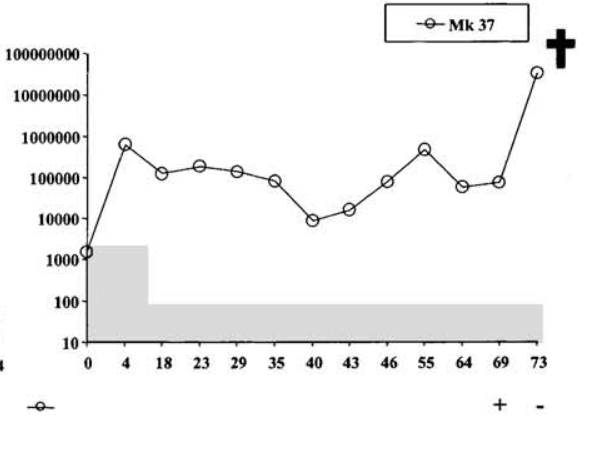

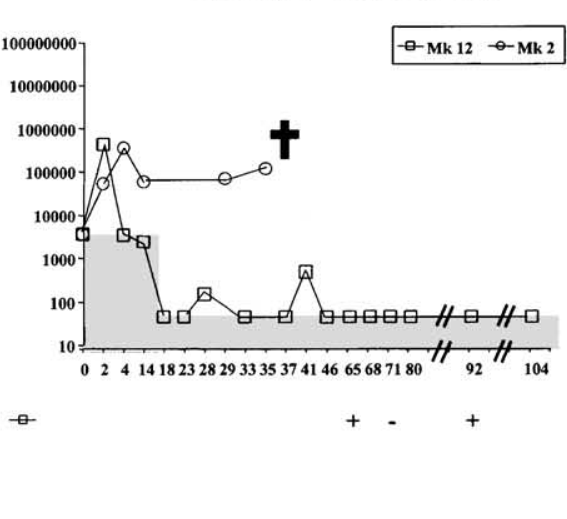

Fig. 1. Plasma viremia and E-DNA in PBMCs up to week 104 after the challenge with SHIV89.6P. (A) Tat protein vaccinated monkeys; (B) tat DNA vaccinated monkeys; (C) adjuvant control and naive control monkeys. The dashed area indicates the cut-off value of $1500 \mathrm{RNA}$ copies/ml until week 14, and of 50 RNA copies/ml from 18 to 104 weeks. E-DNA determinations were performed at the indicated weeks. The signs $(-)$, negative and $(+)$, positive, indicate the absence or presence of E-DNA, respectively.

of the same time points (data not shown). All the vaccinated animals controlling infection (9/12) were negative for virus isolation, proviral DNA and E-DNA in both PBMCs and lymph nodes (Figs. 1 and 2, and data not shown). Among the non-controllers the vaccinated monkeys 55396 and 37 were positive for all assays in both PBMCs and lymph nodes, whereas monkey 54963 was negative for virus isolation in both PBMCs and tissues. In addition, this latter animal had a proviral load higher in lymph nodes

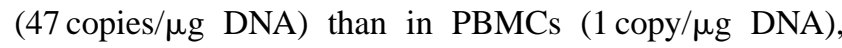
although E-DNA forms were found only in PBMCs. Concerning the control macaques, all overtly infected, lymph nodes from the adjuvant control animals 55123 and 55129 and the naive control monkey 12 were positive for both proviral DNA (43, 5, 36 copies/ $\mu$ g DNA, respectively) and E-DNA. The differences of either proviral DNA or E-DNA 


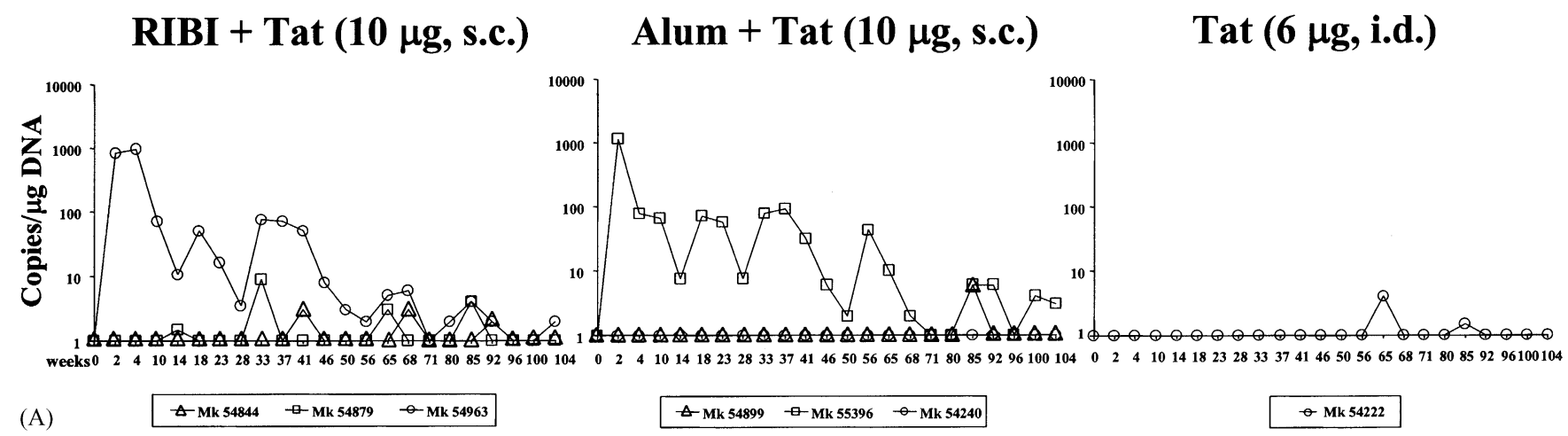

pCV-tat (1 mg, i.m.)

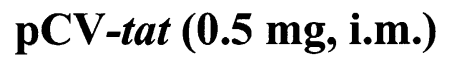

pCV-tat (0.2 mg, i.d.)

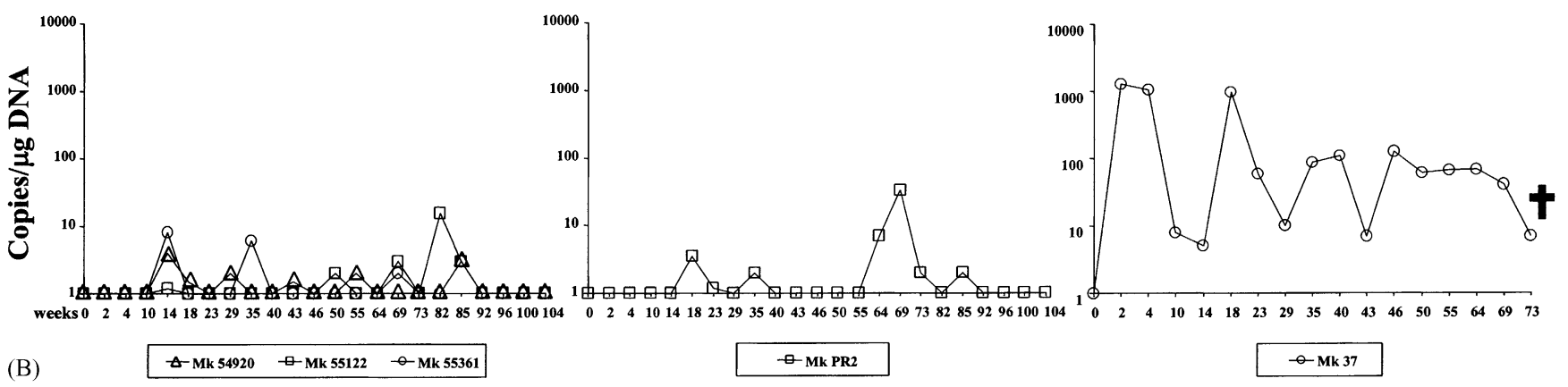

Adjuvant Controls

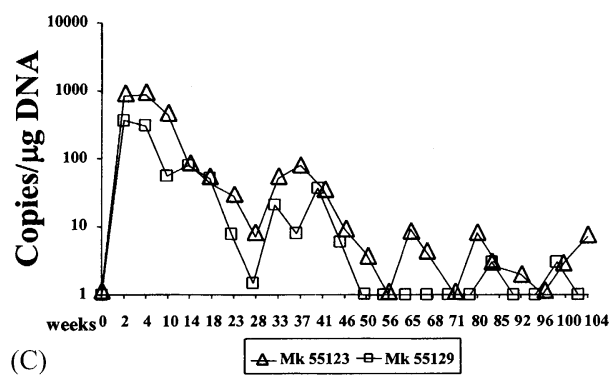

Naive Controls

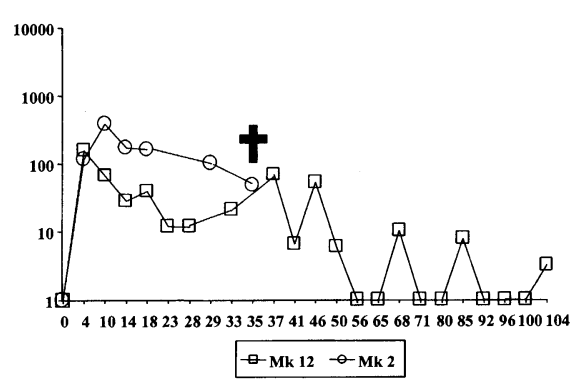

Fig. 2. Proviral DNA copies in PBMCs up to week 104 after the challenge with SHIV89.6P. (A) Tat protein vaccinated monkeys; (B) tat DNA vaccinated monkeys; (C) adjuvant control and naive control monkeys.

levels in lymph nodes of vaccinated (both protected and overtly infected) macaques versus control monkeys were statistically significant (Fisher's exact test: $P$-value $=0.04$ and 0.02 , respectively).

\subsection{Containment of infection is associated with stable Tat-specific CD4 and CD8 T-cell responses}

To determine whether Tat-specific immune responses were durable and whether they correlated with protection, antibodies, lymphoproliferative response and IFN- $\gamma$ ELISpot against Tat were evaluated in all animals at several time points during the follow-up.
Before challenge, anti-Tat IgG titers were high in the monkeys immunized s.c. with the Tat protein and RIBI or Alum adjuvant, low or undetectable in the other vaccinated animals [34-36]. After challenge, anti-Tat IgG titers were stable up to week 14, declined thereafter, and remained detectable up to week 104 only in the monkeys vaccinated s.c. with the Tat protein and RIBI or Alum (Table 1, and data not shown). Thus, exposure to the challenge virus did not result in the induction of anti-Tat antibodies. However, they remained detectable through the all follow-up time in those animals that had developed high titers in response to the Tat vaccine (Table 1 , and data not shown).

Proliferative responses to Tat were detected in most vaccinated monkeys before challenge [34-36]. Early after chal- 


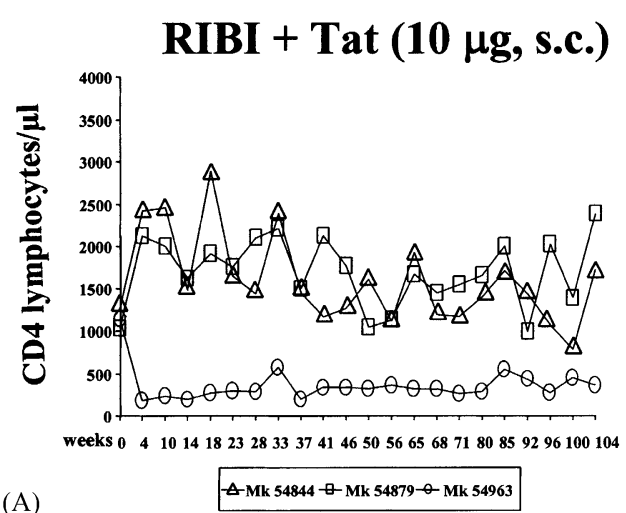

pCV-tat (1 mg, i.m.)

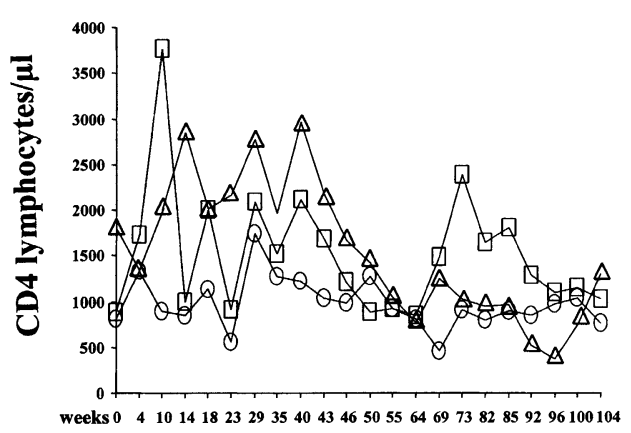

(B)

$\triangle-M k 54920-$ 廿-Mk $55122-0-$ Mk 55361
Alum + Tat (10 $\mu$ g, s.c.)

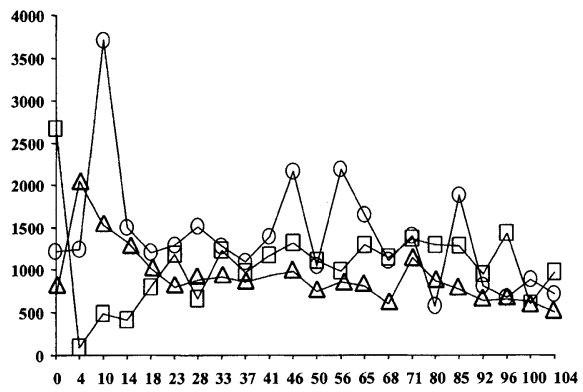

$\triangle-M k 54899+M k 55396$ - - Mk 54240

pCV-tat (0.5 mg, i.m.)

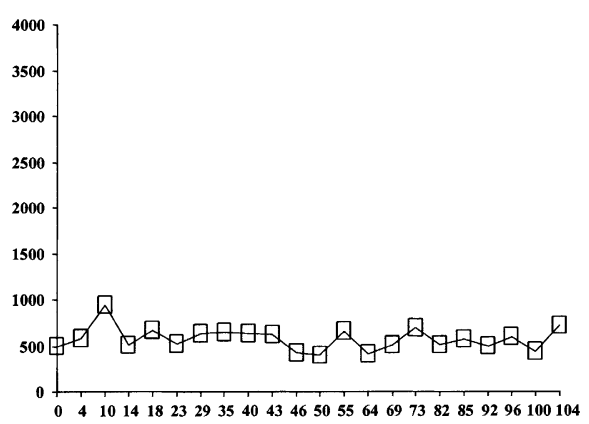

廿-Mk PR2
Tat $(6 \mu g$, i.d.)

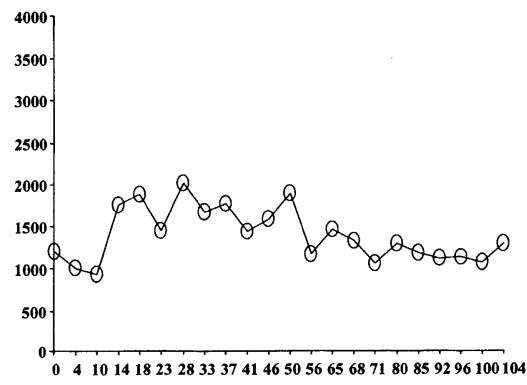

- Mk 54222

pCV-tat (0.2 mg, i.d.)

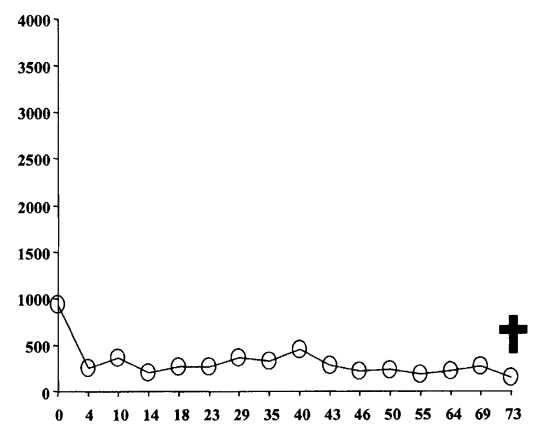

- - Mk 37

\section{Adjuvant Controls}

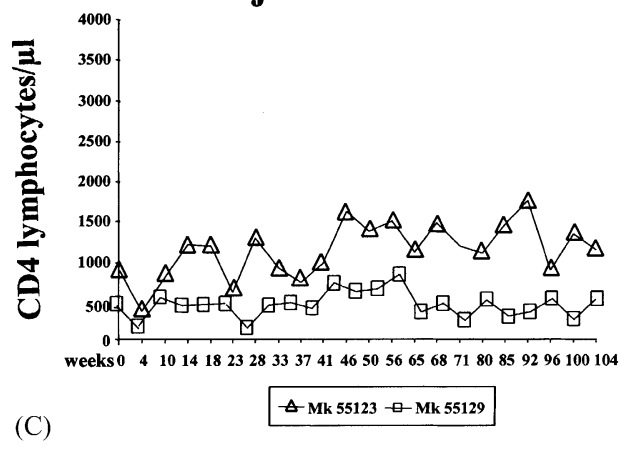

Naive Controls

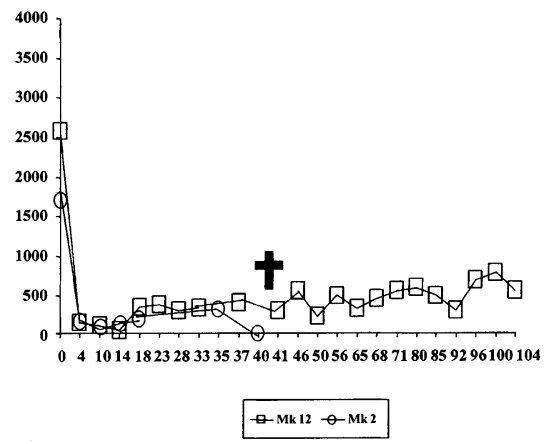

Fig. 3. CD4 T-cell counts up to week 104 after the challenge with SHIV89.6P. (A) Tat protein vaccinated monkeys; (B) tat DNA vaccinated monkeys; (C) adjuvant control and naive control monkeys.

lenge (Table 1, and results not shown), they were high and persistent in all the macaques vaccinated with Tat and RIBI or Alum, lower and sporadic in the monkey vaccinated i.d. with the Tat protein alone and in those immunized with $1 \mathrm{mg}$ of pCV-tat, whereas no responses were detected in monkeys PR2 and 37 that had received 0.5 and $0.2 \mathrm{mg}$ of pCV-tat, i.m. and i.d., respectively. Late after challenge (Table 1, and results not shown), lymphoproliferative responses to Tat increased in four out of five macaques vaccinated with the Tat protein and protected, while they became detectable, although sporadically, in the three monkeys immunized with
$1 \mathrm{mg}$ of pCV-tat. Among the non-controllers a sporadic lymphoproliferative response was detected in monkeys 55129 (control Alum), and 55123 (control RIBI), whereas in the vaccinated and infected animals (monkeys 54963, 55396, and 37) no proliferative response to Tat was detected.

IFN- $\gamma$ ELISpot assay to Tat was positive in eight out of the nine protected macaques (Table 1, and data not shown). Of interest, the highest and most persistent responses were detected in the monkeys vaccinated with Tat and RIBI, including the animal that did not control infection (monkey 54963). Of note, in this latter macaque a strong response 
Table 1

Humoral and cellular immune responses to HIV-1 Env and Tat and SIV Gag early and late after challenge with SHIV89.6P in vaccinated and control animals divided in controllers and non-controllers according to the virological status

\begin{tabular}{|c|c|c|c|c|c|c|c|c|c|c|c|c|}
\hline \multirow[t]{3}{*}{ Monkey } & \multirow[t]{3}{*}{ Group } & \multicolumn{4}{|c|}{ Immune response early (up to week 23) after challenge } & \multicolumn{7}{|c|}{ Immune response late (week 55-104) after challenge } \\
\hline & & \multicolumn{2}{|c|}{ Antibodies to } & \multicolumn{2}{|c|}{$\begin{array}{l}\text { Anti-Tat immune } \\
\text { responses }\end{array}$} & \multicolumn{2}{|c|}{ Antibodies to } & \multicolumn{2}{|c|}{$\begin{array}{l}\text { Anti-Gag immune } \\
\text { responses }\end{array}$} & \multicolumn{3}{|c|}{ Anti-Tat immune responses } \\
\hline & & HIV Env ${ }^{a}$ & SIV $^{\mathrm{a}}$ & $\mathrm{IgG}^{\mathrm{a}}$ & $\begin{array}{l}\text { Proliferative } \\
\text { response }^{\mathrm{b}}\end{array}$ & HIV Env ${ }^{a}$ & SIV $^{\mathrm{a}}$ & $\begin{array}{l}\text { Proliferative } \\
\text { response }^{\mathrm{b}}\end{array}$ & $\begin{array}{l}\text { IFN- } \gamma \\
\text { ELISpot }^{\mathrm{c}}\end{array}$ & $\operatorname{IgG}^{\mathrm{a}}$ & $\begin{array}{l}\text { Proliferative } \\
\text { response }^{\mathrm{b}}\end{array}$ & $\begin{array}{l}\text { IFN- } \gamma \\
\text { ELISpot }^{\mathrm{c}}\end{array}$ \\
\hline \multicolumn{13}{|c|}{ Controllers } \\
\hline $\begin{array}{l}54844 \\
54879\end{array}$ & RIBI + Tat $(10 \mu \mathrm{g}$, s.c. $)$ & $\begin{array}{l}+^{*} \\
+^{*}\end{array}$ & $\begin{array}{l}- \\
-\end{array}$ & $\begin{array}{l}++ \\
+++\end{array}$ & $\begin{array}{l}++ \\
++\end{array}$ & $\begin{array}{l}- \\
-\end{array}$ & $\begin{array}{l}- \\
-\end{array}$ & $\begin{array}{l}- \\
\pm\end{array}$ & $\begin{array}{l}- \\
-\end{array}$ & $\begin{array}{l}++ \\
++\end{array}$ & $\begin{array}{l}++ \\
+++\end{array}$ & $\begin{array}{l}+ \\
++\end{array}$ \\
\hline $\begin{array}{l}54899 \\
54240\end{array}$ & ALUM + Tat $(10 \mu \mathrm{g}$, s.c. $)$ & $\begin{array}{l}+^{*} \\
+^{*}\end{array}$ & $\begin{array}{l}- \\
-\end{array}$ & $\begin{array}{l}++++ \\
+++\end{array}$ & $\begin{array}{l}+ \\
+\end{array}$ & $\begin{array}{l}- \\
-\end{array}$ & $\begin{array}{l}- \\
-\end{array}$ & $\begin{array}{l}- \\
+\end{array}$ & $\begin{array}{l}- \\
-\end{array}$ & $\begin{array}{l}++ \\
+\end{array}$ & $\begin{array}{l}+++ \\
++\end{array}$ & $\begin{array}{l}+ \\
+\end{array}$ \\
\hline 54222 & Tat $(6 \mu$ g, i.d. $)$ & $+^{*}$ & - & \pm & - & - & - & ++ & + & - & +++ & + \\
\hline $\begin{array}{l}54920 \\
55122 \\
55361\end{array}$ & pCV-tat (1 mg, i.m.) & $\begin{array}{l}-^{*} \\
+^{*} \\
+^{*}\end{array}$ & $\begin{array}{l}- \\
- \\
-\end{array}$ & $\begin{array}{l} \pm \\
+ \\
-\end{array}$ & $\begin{array}{l}- \\
- \\
-\end{array}$ & $\begin{array}{l}- \\
- \\
-\end{array}$ & $\begin{array}{l}- \\
- \\
-\end{array}$ & $\begin{array}{l} \pm \\
- \\
\pm\end{array}$ & $\begin{array}{l}- \\
- \\
-\end{array}$ & $\begin{array}{l}- \\
- \\
-\end{array}$ & $\begin{array}{l} \pm \\
\pm \\
-\end{array}$ & $\begin{array}{l}- \\
+ \\
+\end{array}$ \\
\hline PR2 & pCV-tat (0.5 mg, i.m.) & $-^{*}$ & - & - & - & - & - & - & - & - & - & + \\
\hline \multicolumn{13}{|c|}{ Non-controllers } \\
\hline 54963 & RIBI + Tat $(10 \mu \mathrm{g}$, s.c. $)$ & \pm & + & +++ & ++ & + & ++ & + & + & ++ & ++ & ++ \\
\hline 55396 & ALUM + Tat $(10 \mu \mathrm{g}$, s.c. $)$ & + & ++ & +++ & + & +++ & +++ & ++ & + & + & + & - \\
\hline $37^{\dagger}$ & pCV-tat $(0.2 \mathrm{mg}$, i.d. $)$ & + & ++ & + & - & +++ & ++ & \pm & ND & - & - & ND \\
\hline 55123 & Control RIBI & + & +++ & - & - & ++ & +++ & \pm & + & - & \pm & - \\
\hline 55129 & Control ALUM & + & ++ & - & - & + & ++ & +++ & + & - & \pm & - \\
\hline 12 & NIL & + & ++ & ND & ND & +++ & +++ & ND & - & ND & ND & - \\
\hline $2^{\dagger}$ & NIL & + & - & ND & ND & $\mathrm{ND}^{* *}$ & $\mathrm{ND}^{* * *}$ & ND & ND & ND & ND & ND \\
\hline
\end{tabular}

$\dagger$ Monkeys 2 and 37 could not be analyzed since they were euthanized at week 35 and 75 post-challenge, respectively. ND, not done.

a Antibody titers to HIV-1 Env, HIV-1 Tat, and SIV Gag. Reciprocal of the last positive dilution was expressed as:,$-<10 ; \pm, 10-50 ;+, 51-400 ;++, 401-3200 ;+++, 3201-12,800 ;++++$, $>12,800$

${ }^{\mathrm{b}}$ Stimulation index (ratio between antigen-specific and control proliferative response): - , S.I. $<3 ; \pm$, S.I. $\geq 3$ in $33-50 \%$ of determinations; + , S.I. $\geq 3$ in $>50 \%$ of determinations; ++ , S.I. $\geq 3$ in $>50 \%$ of determinations with S.I. peak value between 10 and $30 ;+++$, S.I. $\geq 3$ in $>50 \%$ of determinations with S.I. peak value $>30$.

${ }^{c}$ Data are reported as the mean number of spot forming cells (SFC) per million PBMCs, detected after $18 \mathrm{~h}$ of stimulation with Tat or Gag protein $(5 \mu \mathrm{g} / \mathrm{ml})$, respectively, after substraction of background counts. On the base of data obtained with PBMCs from 24 naive animals a test was considered positive when the number of SFC was greater than 20 per million PBMCs. Arbitrary scoring (SFC per million PBMCs):,$-<20 ;+, 20-100 ;++,>100$.

* Anti-HIV Ab detected by IVAP in the supernatants of PBMCs stimulated with PWM

** ++ , at the time of sacrifice (week 35 ).

*** - , at the time of sacrifice (week 35 ). 
to Tat correlated with negative virus isolation and no detectable virus replication (E-DNA) in lymph nodes. In contrast, in monkey 55396 (Tat + Alum), from which virus was frequently isolated, no production of IFN- $\gamma$ in response to Tat was detected. Similarly, none of the adjuvant control or naive control animals produced IFN- $\gamma$ in response to Tat. Thus, late after challenge eight out of nine controllers produced IFN- $\gamma$ in response to Tat, as compared to one out of the five non-controllers tested.

Overall, the Tat-specific proliferative and IFN- $\gamma$ ELISpot responses were higher and more frequent in the animals that controlled infection and either sporadic, absent, or lost over time in the monkeys unable to contain primary infection.

\subsection{Immune responses to structural SIV/HIV antigens in protected monkeys reveal a pattern suggestive of an abortive infection}

During the follow-up the Ab against SIV antigens or the HIV envelope became undetectable in the controllers, which showed very low titers $(<1: 10)$ early after challenge. Conversely, anti-SIV and anti-HIV Env titers remained high or increased in the non-controllers (Table 1, and data not shown). Similarly, lymphoproliferative responses to the Gag protein or to a pool of Gag peptides were absent or sporadic in $7 / 9$ of the controllers (Table 1, and data not shown). In contrast, three out of the six non-controllers analysed had higher and persistent responses. This difference was statistically significant (Student's $t$-test $P<0.05$ ).

IFN- $\gamma$ ELISpot assay against Gag were positive in 1/9 vaccinated and protected monkeys and in four out of the five non-controllers analyzed. Of note, a direct correlation was found between IFN- $\gamma$ production and the frequency of virus isolation. The difference between the mean values of Gag-specific IFN- $\gamma$ secreting cells detected in the controllers versus the non-controllers was statistically significant (Student's $t$-test: $P$-value $<0.05$ ).

Thus, robust and persistent Gag-specific B- and T-cell responses were detected only in animals unable to control virus replication. In contrast, they were low, transient or undetectable in all the vaccinated animals containing primary virus replication. This pattern is suggestive of an abortive infection in protected animals.

\section{Discussion}

Vaccination with a biologically active Tat protein or pCV-tat controlled infection with the highly pathogenic SHIV89.6P preventing CD4 T-cell decline and disease onset. Here we show that protection after challenge was prolonged since no CD4 T-cell decline nor active virus replication was detected in all protected animals neither in blood nor in lymph nodes for the entire follow-up period (104 weeks). In addition, Tat vaccination elicited long-term memory $\mathrm{T}$-cell responses in the absence of any vaccine boosting.
Containment of viral load is considered a critical parameter in the assessment of vaccine efficacy [47-50], since high levels of viral load early after infection can be predictive of disease progression [43,51-58]. Indeed, in the vaccinated and protected monkeys from this study, viral load (either cell- or plasma-associated) was persistently low or undetectable and CD4 T-cell decline did not occur. These data were confirmed by the determination of unintegrated forms of DNA, a very sensitive marker for active viral replication [59] as compared to plasma viremia $[44,45]$. In our study, detection of circular E-DNA correlated with the presence of a detectable plasma viremia during the acute phase of infection, in agreement with previous reports in both the HIV [60,61] and the SIV model [62]. In fact, in the monkey model the presence of circular E-DNA was found to correlate with low CD4:CD8 ratio in lymphoid organs and with AIDS development [62]. Noteworthy, while plasma viremia became undetectable, circular E-DNA remained detectable during chronic infection in the non-controllers indicating persistency of an active infection. In contrast, E-DNA was detected only once in PBMCs from 3/9 protected animals. The results of virus containment were confirmed by the analyses of lymph node biopsies showing undetectable proviral DNA, virus isolation and circular viral DNA in all the controllers, whereas one or more of these viral parameters were positive in the non-controllers. Finally, two of the seven non-controllers showed severe worsening of the clinical conditions and died.

Immune responses to the viral antigens showed a different and opposite pattern in the two groups of animals. In particular, Tat-specific CD4 and CD8 T-cell responses (proliferative response and IFN- $\gamma$ ELISpot, respectively) were consistently detected in all the controllers, as compared to the non-controllers (vaccinated, adjuvant controls or naive controls) in which they were absent or transient. Vice versa, CD4 and CD8 T-cell responses to Gag were generally high and persistent in the non-controllers, whereas they were undetectable or low and transient in the protected vaccinees. Thus, the presence of CD4 and CD8 T-cell responses to Gag correlated significantly with active virus replication.

The relevance of CTL responses against HIV-1 and SIV early regulatory proteins Tat, Rev and Nef has been addressed in recent reports aimed at defining the role of CTLs in controlling viremia and the factors governing the selection of escaping mutants, the only parameter presently available to measure CTLs efficacy. In a SIV model utilizing a molecular clone for the challenge, a strong correlation was found between the resolution of plasma viremia and the detection of a dominant CTL response against a Tat epitope (Tat ${ }_{28-35}$ SL8) leading to the appearance of viral variants with an apparently reduced fitness [31]. Subsequent studies demonstrated that CTLs with high functional avidity for the early and intermediate proteins Tat, Nef and Vpr were the major factor driving the selection of immune escape variants during acute SIV infection [63]. More recent data measuring inhibition of HIV-1 replication by CTLs clones with 
known avidity and specificity indicate that, in vitro, the fine epitope specificity might be the most important factor at determining control of virus replication and selection of virus variants [64]. In both cases, CTLs against regulatory proteins were responsible of rapid selection of escape variants indicating a strong immune pressure. It has been proposed that because of their early expression, targeting regulatory proteins, rather than structural antigens, may be extremely advantageous to the host because CTLs will impact on the virus replication cycle at a critical step and for a prolonged time [65]. Therefore, vaccines aimed at eliciting a large number of polyclonal CTLs against these antigens may prove effective at blocking virus expression during the early phases of the acute infection, minimizing the selection of escape variants. Along this line, a novel vaccine approach based on a polyvalent chimeric protein in which the genes coding for HIV-1 Tat, Rev and Nef has been recently developed and found safe and immunogenic in macaques [66].

It is tempting to speculate that in our study vaccination with either Tat protein or tat-DNA controlled primary infection at its early stages allowing containment of virus spread in blood and tissues to undetectable levels, which were sufficient to ensure development and maintenance of long-term anti-Tat memory and to elicit weak anti-Gag T-helper but not CTL responses in the protected monkeys. This pattern of immune responses, together with the virological data, suggests that in vaccinated and protected animals infection occurred, but it was abortive. In addition, it suggests that immune responses to Gag are not necessary to ensure long-term protection in monkeys that have contained infection early after challenge. However, development of anti-Gag humoral and cellular immune responses in overtly infected monkeys (non-controllers) may contribute to lower the viral load and partially restore the CD4 T-cell number over time, mimicking the transitory control that marks the resolution of the acute phase in the natural history of HIV-1 infection in humans.

Recently, results have been reported showing that the immunization of rhesus monkeys with the Tat protein $[67,68]$ was safe and immunogenic but failed to induce a significant control of viral replication following challenge with SIV or SHIV89.6P pathogenic viruses. However, several and key differences in the study design including dose and type of Tat (SIV and HIV), monkey species, adjuvant, dose and schedule of immunization, virus dose and route of challenge may account for these conflicting results. Another key difference may be represented by the conformation of the Tat protein. Specifically, we found that small differences in Tat which can be detected only by analytical HPLC and by uptake by dendritic cells (and not by other assays), make important differences in the targeting and effects of Tat on dendritic cells which are key to initiate proper immune responses ([32], and unpublished data). Further, our results are in agreement with reports from pre-clinical $[39,69]$ and clinical $[40,41]$ trials indicating that vaccination with Tat is safe, immunogenic and effective at controlling virus replication and disease progression in the monkey model. These data suggest that a native Tat protein or tat DNA should be included in future vaccine designs, particularly in prime-boost regimens. Based on these data, and on our recent results from field studies in Africa indicating cross-clade recognition of Tat by anti-Tat Ab [28], preventive and therapeutic phase I trials are currently under way in Italy. In addition, a second generation of vaccine approaches combining Tat with other antigens, such as Env and Gag, are under development to verify whether a rationally designed antigen combination can increase efficacy and long-term protection against homologous as well as heterologous virus clades.

\section{Acknowledgements}

We thank A. Comini for the veterinary assistance; E. Iale, F. Incitti, F. Varano, N. Verrone, A. Marini, A. Avitabile, M. Chiodi, M. Azzetti and S. Alessandrini, for hematoclinical analysis of cynomolgus samples and for the handling of the animal facility; R. Belli, F. De Angelis, M. Pace, E. Salvi C. Rovetto, F. Carlini, M.G. Mancini, S. Farcomeni and D. Fulgenzi (Laboratory of Virology, Istituto Superiore di Sanità) for technical help; N. Esposito for statistical analyses. We also thank A. Lippa and P. Sergiampietri for the editorial assistance. This work was supported by grants from the IX AIDS Project, the Italian Concerted Action on HIV-AIDS vaccine development (ICAV), ISS, Rome, Italy.

\section{References}

[1] Arya SK, Guo C, Josephs SF, Wong-Staal F. Trans-activator gene of human T-lymphotropic virus type III (HTLV-III). Science 1985;229(4708):69-73.

[2] Fisher AG, Feinberg MB, Josephs SF, Harper ME, Marselle LM, Reyes G, et al. The trans-activator gene of HTLV-III is essential for virus replication. Nature 1986;320(6060):367-71.

[3] Wu Y, Marsh JW. Selective transcription and modulation of resting $\mathrm{T}$ cell activity by preintegrated HIV DNA. Science 2001;293(5534):1503-6.

[4] Sodroski J, Patarca R, Rosen C, Wong-Staal F, Haseltine W. Location of the trans-activating region on the genome of human T-cell lymphotropic virus type III. Science 1985;229(4708):74-7.

[5] Cullen BR, Greene WC. Regulatory pathways governing HIV-1 replication. Cell 1989;58(3):423-6.

[6] Ensoli B, Buonaguro L, Barillari G, Fiorelli V, Gendelman R, Morgan RA, et al. Release, uptake, and effects of extracellular human immunodeficiency virus type 1 Tat protein on cell growth and viral transactivation. J Virol 1993;67(1):277-87.

[7] Chang HK, Gallo RC, Ensoli B. Regulation of cellular gene expression and function by the human immunodeficiency virus type 1 Tat protein. J Biomed Sci 1995;2(3):189-202.

[8] Ensoli B, Barillari G, Salahuddin SZ, Gallo RC, Wong-Staal F. Tat protein of HIV-1 stimulates growth of cells derived from Kaposi's sarcoma lesions of AIDS patients. Nature 1990;345(6270):84-6.

[9] Chang HC, Samaniego F, Nair BC, Buonaguro L, Ensoli B. HIV-1 Tat protein exits from cells via a leaderless secretory pathway and binds to extracellular matrix-associated heparan sulfate proteoglycans through its basic region. AIDS 1997;11(12):1421-31. 
[10] Frankel AD, Pabo CO. Cellular uptake of the tat protein from human immunodeficiency virus. Cell 1988;55(6):1189-93.

[11] Fawell S, Seery J, Daikh Y, Moore C, Chen LL, Pepinsky B, et al. Tat-mediated delivery of heterologous proteins into cells. Proc Natl Acad Sci USA 1994;91(2):664-8.

[12] Huang L, Bosch I, Hofmann W, Sodroski J, Pardee AB. Tat protein induces human immunodeficiency virus type 1 (HIV-1) coreceptors and promotes infection with both macrophage-tropic and T-lymphotropic HIV-1 strains. J Virol 1998;72(11):8952-60.

[13] Secchiero P, Zella D, Capitani S, Gallo RC, Zauli G. Extracellular HIV-1 tat protein up-regulates the expression of surface CXC-chemokine receptor 4 in resting CD4+ T cells. J Immunol 1999;162(4): 2427-31.

[14] Weiss JM, Nath A, Major EO, Berman JW. HIV-1 Tat induces monocyte chemoattractant protein-1-mediated monocyte transmigration across a model of the human blood-brain barrier and up-regulates CCR5 expression on human monocytes. J Immunol 1999;163(5):2953-9.

[15] de Paulis A, De Palma R, Di Gioia L, Carfora M, Prevete N, Tosi G, et al. Tat protein is an HIV-1-encoded beta-chemokine homolog that promotes migration and up-regulates CCR3 expression on human Fc epsilon RI+ cells. J Immunol 2000;165(12):7171-9.

[16] Viscidi RP, Mayur K, Lederman HM, Frankel AD. Inhibition of antigen-induced lymphocyte proliferation by Tat protein from HIV-1. Science 1989;246(4937):1606-8.

[17] Subramanyam M, Gutheil WG, Bachovchin WW, Huber BT. Mechanism of HIV-1 Tat induced inhibition of antigen-specific T cell responsiveness. J Immunol 1993;150(6):2544-53.

[18] Ensoli B, Gendelman R, Markham P, Fiorelli V, Colombini S, Raffeld M, et al. Synergy between basic fibroblast growth factor and HIV-1 Tat protein in induction of Kaposi's sarcoma. Nature 1994;371(6499):674-80.

[19] Li CJ, Friedman DJ, Wang C, Metelev V, Pardee AB. Induction of apoptosis in uninfected lymphocytes by HIV-1 Tat protein. Science 1995;268(5209):429-31.

[20] Zagury JF, Sill A, Blattner W, Lachgar A, Le Buanec H, Richardson $\mathrm{M}$, et al. Antibodies to the HIV-1 Tat protein correlated with nonprogression to AIDS: a rationale for the use of Tat toxoid as an HIV-1 vaccine. J Hum Virol 1998;1(4):282-92.

[21] Barillari G, Sgadari C, Fiorelli V, Samaniego F, Colombini S, Manzari $\mathrm{V}$, et al. The Tat protein of human immunodeficiency virus type-1 promotes vascular cell growth and locomotion by engaging the alpha5beta 1 and alphavbeta 3 integrins and by mobilizing sequestered basic fibroblast growth factor. Blood 1999;94(2):663-72.

[22] Barillari G, Sgadari C, Palladino C, Gendelman R, Caputo A, Morris $\mathrm{CB}$, et al. Inflammatory cytokines synergize with the HIV-1 Tat protein to promote angiogenesis and Kaposi's sarcoma via induction of basic fibroblast growth factor and the alpha $\mathrm{v}$ beta 3 integrin. $\mathrm{J}$ Immunol 1999;163(4):1929-3195.

[23] Reiss P, Lange JM, de Ronde A, de Wolf F, Dekker J, Debouck C, et al. Speed of progression to AIDS and degree of antibody response to accessory gene products of HIV-1. J Med Virol 1990;30(3):163-8.

[24] Rodman TC, To SE, Hashish H, Manchester K. Epitopes for natural antibodies of human immunodeficiency virus (HIV)-negative (normal) and HIV-positive sera are coincident with two key functional sequences of HIV Tat protein. Proc Natl Acad Sci USA 1993;90(16):7719-23.

[25] Re MC, Furlini G, Vignoli M, Ramazzotti E, Roderigo G, De RV, et al. Effect of antibody to HIV-1 Tat protein on viral replication in vitro and progression of HIV-1 disease in vivo. J Acquir Immune Defic Syndr Hum Retrovirol 1995;10(4):408-16.

[26] Zagury D, Lachgar A, Chams V, Fall LS, Bernard J, Zagury JF, et al. Interferon alpha and Tat involvement in the immunosuppression of uninfected T cells and C-C chemokine decline in AIDS. Proc Natl Acad Sci USA 1998;95(7):3851-6.

[27] Re MC, Vignoli M, Furlini G, Gibellini D, Colangeli V, Vitone F, et al. Antibodies against full-length Tat protein and some low-molecular-weight Tat-peptides correlate with low or undetectable viral load in HIV-1 seropositive patients. J Clin Virol 2001;21(1):819.

[28] Buttò S, Fiorelli V, Tripiciano A, Ruiz-Alvarez MJ, Scoglio A, Ensoli F, et al. Cross-recognition of the Clade B HIV-1 Tat protein vaccine candidate by antibodies from HIV-1-infected Italian. Ugandan and South African individuals. J Infect Dis 2003;188:1171-80.

[29] van Baalen CA, Pontesilli O, Huisman RC, Geretti AM, Klein MR, de Wolf $\mathrm{F}$, et al. Human immunodeficiency virus type $1 \mathrm{Rev-}$ and Tat-specific cytotoxic $\mathrm{T}$ lymphocyte frequencies inversely correlate with rapid progression to AIDS. J Gen Virol 1997;78(Pt 8):1913-8.

[30] Addo MM, Altfeld M, Rosenberg ES, Eldridge RL, Philips MN, Habeeb K, et al. The HIV-1 regulatory proteins Tat and Rev are frequently targeted by cytotoxic T lymphocytes derived from HIV-1infected individuals. Proc Natl Acad Sci USA 2001;98(4):1781-6.

[31] Allen TM, O'Connor DH, Jing P, Dzuris JL, Mothe BR, Vogel TU, et al. Tat-specific cytotoxic T lymphocytes select for SIV escape variants during resolution of primary viraemia. Nature 2000;407(6802):38690.

[32] Fanales-Belasio E, Moretti S, Nappi F, Barillari G, Micheletti F, Cafaro A, et al. Native HIV-1 Tat protein targets monocyte-derived dendritic cells and enhances their maturation, function, and antigen-specific T cell responses. J Immunol 2002;168(1):197-206.

[33] Kim DT, Mitchell DJ, Brockstedt DG, Fong L, Nolan GP, Fathman $\mathrm{CG}$, et al. Introduction of soluble proteins into the MHC class I pathway by conjugation to an HIV tat peptide. J Immunol 1997;159(4):1666-8.

[34] Cafaro A, Caputo A, Fracasso C, Maggiorella MT, Goletti D, Baroncelli S, et al. Control of SHIV-89.6P-infection of cynomolgus monkeys by HIV-1 Tat protein vaccine. Nat Med 1999;5(6):643-50.

[35] Cafaro A, Caputo A, Maggiorella MT, Baroncelli S, Fracasso C, Pace M, et al. SHIV89.6P pathogenicity in cynomolgus monkeys and control of viral replication and disease onset by human immunodeficiency virus type 1 Tat vaccine. J Med Primatol 2000;29(3-4):193208.

[36] Cafaro A, Titti F, Fracasso C, Maggiorella MT, Baroncelli S, Caputo A, et al. Vaccination with DNA containing tat coding sequences and unmethylated $\mathrm{CpG}$ motifs protects cynomolgus monkeys upon infection with simian/human immunodeficiency virus (SHIV89.6P). Vaccine 2001;19(2022):2862-77.

[37] Caselli E, Betti M, Grossi MP, Balboni PG, Rossi C, Boarini C, et al. DNA immunization with HIV-1 tat mutated in the trans activation domain induces humoral and cellular immune responses against wild-type Tat. J Immunol 1999;162(9):5631-8.

[38] Caputo A, Betti M, Altavilla G, Bonaccorsi A, Boarini C, Marchisio $\mathrm{M}$, et al. Micellar-type complexes of tailor-made synthetic block copolymers containing the HIV-1 tat DNA for vaccine application. Vaccine 2002;20(17-18):2303-17.

[39] Osterhaus AD, van Baalen CA, Gruters RA, Schutten M, Siebelink $\mathrm{CH}$, Hulskotte EG, et al. Vaccination with Rev and Tat against AIDS. Vaccine 1999;17(20-21):2713-4.

[40] Calarota S, Bratt G, Nordlund S, Hinkula J, Leandersson AC, Sandstrom E, et al. Cellular cytotoxic response induced by DNA vaccination in HIV-1-infected patients. Lancet 1998;351(9112):1320 5.

[41] Calarota SA, Leandersson AC, Bratt G, Hinkula J, Klinman DM, Weinhold KJ, et al. Immune responses in asymptomatic HIV-1infected patients after HIV-DNA immunization followed by highly active antiretroviral treatment. J Immunol 1999;163(4):2330-8.

[42] Karlsson GB, Halloran M, Li J, Park IW, Gomila R, Reimann KA, et al. Characterization of molecularly cloned simian-human immunodeficiency viruses causing rapid CD4+ lymphocyte depletion in rhesus monkeys. J Virol 1997;71(6):4218-25.

[43] Ten Haaft P, Verstrepen B, Uberla K, Rosenwirth B, Heeney J. A pathogenic threshold of virus load defined in simian immunodeficiency virus- or simian-human immunodeficiency virus-infected macaques. J Virol 1998;72(12):10281-5. 
[44] Sharkey ME, Teo I, Greenough T, Sharova N, Luzuriaga K, Sullivan JL, et al. Persistence of episomal HIV-1 infection intermediates in patients on highly active anti-retroviral therapy. Nat Med 2000;6(1):76-81.

[45] Cara A, Vargas Jr J, Keller M, et al. Circular viral DNA and anomalous junction sequence in PBMC of HIV-infected individuals with no detectable plasma HIV RNA. Virology 2002;292(1):1-5.

[46] Titti F, Sernicola L, Geraci A, Panzini G, Di Fabio S, Belli $\mathrm{R}$, et al. Live attenuated simian immunodeficiency virus prevents super-infection by cloned SIVmac251 in cynomolgus monkeys. J Gen Virol 1997;78(Pt 10):2529-39.

[47] Heeney JL. Primate models for AIDS vaccine development. AIDS 1996;10(Suppl A):S115-22.

[48] Ensoli B, Cafaro A. Novel strategies toward the development of an effective vaccine to prevent human immunodeficiency virus infection or acquired immunodeficiency virus. In: Volberding PA, Jacobson MA, editors. AIDS clinical review 2000/2001. New York: Marcel Dekker; 2001. p. 23-61.

[49] Kent SJ, Ada GL, Hayes E, Lewis IM. Determining the immune mechanisms of protection from AIDS: correlates of immunity and the development of syngeneic macaques. Immunol Rev 2001;183(1):94108.

[50] Mooij P, Heeney JL. Rational development of prophylactic HIV vaccines based on structural and regulatory proteins. Vaccine 2001;20(3-4):304-21.

[51] Henrard DR, Phillips JF, Muenz LR, Blattner WA, Wiesner D, Eyster ME, et al. Natural history of HIV-1 cell-free viremia. JAMA 1995;274(7):554-8.

[52] Mellors JW, Rinaldo Jr CR, Gupta P, White RM, Todd JA, Kingsley LA. Prognosis in HIV-1 infection predicted by the quantity of virus in plasma. Science 1996;272(5265): 1167-70.

[53] Lifson JD, Nowak MA, Goldstein S, Rossio JL, Kinter A, Vasquez $\mathrm{G}$, et al. The extent of early viral replication is a critical determinant of the natural history of simian immunodeficiency virus infection. J Virol 1997;71(12):9508-14.

[54] Watson A, Ranchalis J, Travis B, McClure J, Sutton W, Johnson $\mathrm{PR}$, et al. Plasma viremia in macaques infected with simian immunodeficiency virus: plasma viral load early in infection predicts survival. J Virol 1997;71(1):284-90.

[55] Kaufmann GR, Cunningham P, Zaunders J, Law M, Vizzard J, Carr A, et al. Impact of early HIV-1 RNA and T-lymphocyte dynamics during primary HIV-1 infection on the subsequent course of HIV-1 RNA levels and CD4+ T-lymphocyte counts in the first year of HIV-1 infection. Sydney Primary HIV Infection Study Group. J Acquir Immune Defic Syndr 1999;22(5):437-44.

[56] Anastos K, Kalish LA, Hessol N, Weiser B, Melnick S, Burns D, et al. The relative value of CD4 cell count and quantitative HIV-1 RNA in predicting survival in HIV-1-infected women: results of the women's interagency HIV study. AIDS 1999;13(13):1717-26.
[57] Lyles CM, Dorrucci M, Vlahov D, Pezzotti P, Angarano G, Sinicco A, et al. Longitudinal human immunodeficiency virus type 1 load in the italian seroconversion study: correlates and temporal trends of virus load. J Infect Dis 1999;180(4):1018-24.

[58] Staprans SI, Dailey PJ, Rosenthal A, Horton C, Grant RM, Lerche $\mathrm{N}$, et al. Simian immunodeficiency virus disease course is predicted by the extent of virus replication during primary infection. J Virol 1999;73(6):4829-39.

[59] Cara A, Reitz Jr MS. New insight on the role of extrachromosomal retroviral DNA. Leukemia 1997;11(9):1395-9.

[60] Panther La, Coombs RW, Zeh JE, Collier AC, Corey L. Unintegrated circular HIV-1 DNA in the peripheral mononuclear cells of HIV-1 infected subjects: association with high levels of plasma HIV-1 RNA, rapid decline in CD4 count, and clinical progression to AIDS. J Acquir Immune Defic Syndr Hum Retrovirol 1998;17(4):303-13.

[61] Panther LA, Coombs RW, Aung SA, Dela RC, Gretch D, Corey L. Unintegrated HIV-1 circular 2-LTR proviral DNA as a marker of recently infected cells: relative effect of recombinant CD4, zidovudine, and saquinavir in vitro. J Med Virol 1999;58(2):16573.

[62] Rosenberg YJ, Lewis MG, Leon EC, Cafaro A, Eddy GA, Greenhouse JJ. Viral DNA burden and decline in percentage of CD4 positive cells in the lymphoid compartment of SIV-infected macaques. AIDS Res Hum Retroviruses 1994;10(10):1269-77.

[63] O'Connor DH, Allen TM, Vogel TU, Jing P, DeSouza IP, Dodds E, et al. Acute phase cytotoxic T lymphocyte escape is a hallmark of simian immunodeficiency virus infection. Nat Med 2002;8(5):493-9.

[64] Yang OO, Sarkis PT, Ali A, Harlow JD, Brander C, Kalams SA, et al. Determinants of HIV-1 mutational escape from cytotoxic T lymphocytes. J Exp Med 2003;197(10):1365-75.

[65] Gruters RA, van Baalen CA, Osterhaus ADME. The advantage of early recognition of HIV-infected cells by cytotoxic T-lymphocytes. Vaccine 2002;20(15):2011-5.

[66] Hel Z, Tryniszewska E, Tsai WP, Johnson JM, Harrod R, Fullen J, et al. Design and in vivo immunogenicity of a polyvalent vaccine based on SIVmac regulatory genes. DNA Cell Biol 2002;21(9):619_ 26.

[67] Allen TM, Mortara L, Mothe BR, Liebl M, Jing P, Calore B, et al. Tat-vaccinated macaques do not control simian immunodeficiency virus SIVmac239 replication. J Virol 2002;76(8):4108-12.

[68] Silvera P, Richardson MW, Greenhouse J, Yalley-Ogunro J, Shaw N, Mirchandani J, et al. Outcome of Simian-human immunodeficiency virus strain $89.6 \mathrm{p}$ challenge following vaccination of rhesus macaques with human immunodeficiency virus Tat protein. J Virol 2002;76(8):3800-9.

[69] Pauza CD, Trivedi P, Wallace M, Ruckwardt TJ, Le Buanec $\mathrm{H}, \mathrm{Lu} \mathrm{W}$, et al. Vaccination with tat toxoid attenuates disease in simian/HIV-challenged macaques. Proc Natl Acad Sci USA 2000;97(7):3515-9. 